\title{
Acts of the Russian Federation Constitutional Court in the context of criminal law linkages
}

\author{
Vladimir Pavlovich Konyakhin ${ }^{1}$, Tatyana Yurievna Batyutina $^{1}$, Ruslan Georgievich \\ Aslanyan $^{1}$, and Manas Kapasovich Intykbaev ${ }^{2}$ \\ ${ }^{1}$ Kuban State University, Department of Criminal Law and Criminology, Krasnodar, Russia \\ ${ }^{2}$ Central Kazakhstan Academy, Department of Criminal Law and Procedure, Almaty, Kazakhstan
}

\begin{abstract}
The regulatory certainty of the provisions of the Criminal Code of the Russian Federation is ensured by the presence of systemic hierarchical links between different legal prescriptions, including of the other-branch affiliation. Since the Russian legislation does not provide for the authentic interpretation of federal laws, the Russian Federation Constitutional Court plays an important role in the resolution of complicated issues of enforcement of the Criminal Code of the Russian Federation. As a rule, the doctrine gives a characteristic of particular decisions taken by it through the prism of problems of classification of specific crimes. However, proceeding from the growing scientific interest in interdisciplinary research, it seems necessary to accumulate the major legal provisions of the said court in terms of enforcement of the criminal law, with regard for its inter-sectoral bonds. The purpose of the research is to generalise the conclusions of the Russian Federation Constitutional Court on such fundamental issues as the grounds for criminal liability, timeframe validity of a criminal law, differentiation between crimes and administrative offences, prejudgement - and search of the optimal algorithm for their resolution in the future on this basis. The methodological basis of the study is represented by the general scientific methods of cognition: dialectical and systemic-structural; and as concerns the specific scientific methods - by the legalistic method. Following the analysis of a number of resolutions and rulings of the Russian Federation Constitutional Court for the period 2003-2020, an algorithm was developed for enforcement of the regulatory prescriptions of the Criminal Code of the Russian Federation in the context of its inter-branch linkages. It was found out, on the basis of the study of sentences passed by the Russian courts, that the most common mistakes of law enforcement officers in extrapolating the legal provisions of the Russian Federation Constitutional Court within the framework of particular criminal cases are connected with incorrect interpretation of factual circumstances as well as the facts of transcending the content of the relevant norms of the Criminal Code of the Russian Federation.
\end{abstract}

Keywords: legal provisions, interdisciplinary differentiation, decriminalisation, differentiation of crimes, administrative offences

${ }^{1 *}$ Corresponding author: vladkon54@mail.ru 


\section{Introduction}

The systemic analysis shows that a number of resolutions and rulings of the Russian Federation (RF) Constitutional Court contain extremely important legal provisions on the issues of enforcement of criminal legislation in terms of compliance of the latter with the legislative language and the spirit of the Constitution of the Russian Federation. Such legal provisions may represent acts of "negative lawmaking", factually cancelling the validity of the penal law regulations that contradict to the Constitution of the Russian Federation [1]; or they may serve as acts of statutory official interpretation, when they specify (detail) the meaning and content of particular provisions of the criminal law through the prism of the Constitution of the Russian Federation. It is sometimes quite difficult to draw a line between the interpretation and own lawmaking by the Constitutional Courts of different states; however, the ongoing discussion about the legal nature of acts passed by them [2-6] does not cancel their mandatory nature.

\section{$2 \quad$ Methods}

Since the regulatory certainty of the provisions of the Criminal Code of the Russian Federation (CC RF) is often ensured by the presence of systemic hierarchical links between different legal prescriptions, including those establishing liability for related offences [7], while the doctrine respectively provides, as a rule, a characteristic only of particular decisions made by the RF Constitutional Court [8], the authors deem it necessary to bring together the major conceptual positions of the said court regarding the enforcement of the $\mathrm{CC} \mathrm{RF}$, with regard for its inter-branch linkages.

\section{$3 \quad$ Results and discussion}

\section{Criminal law:}

1) The constitutional nature of the blanket construction as such is not doubted in cases where the rules entailing criminal liability, in case of their non-observance, are established by subordinate laws [7]. For instance, in order to classify a crime under Article 324 of the CC RF, it is necessary to turn to the decrees of the Russian Federation President.

\section{Grounds for criminal liability:}

2) The absence of regulatory provisions for a particular issue in the statutory legal acts which are referred to by the blanket disposition of a specific article of the CC RF does not allow a person to realise the substance of restrictions and prohibitions and to foresee the penal law consequences of his/her behaviour. In case of such a gap in the regulatory legislation, pending its elimination (and in the absence of a special instruction pointing to the need to take a particular statutory legal act into account), suing a person is unlawful and may be interpreted as enforcement of the criminal law by analogy.

For instance, citizens of the Republic of Kazakhstan Nedashkovsky and Yakovlev were found guilty of committing a crime under Part 1 of Article $226^{1}$ of the CC RF: they transported a potent substance 1-testosterone across the state border of the Russian Federation with the Republic of Kazakhstan, for personal use. The RF Constitutional Court identified a gap in the legal regulation of this issue and took a decision to review the sentences against the above persons [9].

Validity of the criminal law over time (in the context of decriminalisation):

3) Decriminalisation of a deed may be effected not only by introducing appropriate amendments to the criminal law, but also by abolishing the statutory prescriptions in a different branch to which the blanket norms of the criminal law referred, or by limiting the 
scope of criminal law regulation as a result of legislative recognition of a deed as not representing social danger attributable to crimes specifically and thus entailing administrative or other, more lenient liability [10]. As known, the limitation of the scope of criminal law regulation has been repeatedly effected by establishing the scope of petty theft by the RF Administrative Offence Code (AOC). The RF Constitutional Court also established: 4) if, in accordance with a concrete federal law, a deed ceases to be recognised as criminal, but is handled in terms of a new administrative corpus delicti, then the classification of the deed is made under a corresponding (albeit introduced after its commission) article of the RF AOC [11].

At the same time, the universal character of the algorithm incorporated in the above legal provisions of the RF Constitutional Court is an issue still open currently and requiring further elaboration. The specific features of the rules for time-duration enforcement of statutory legal acts envisaged by the criminal law were pointed out by Pikurov. The said author states that the enforcement of the criminal law does not depend on changes in regulations involving technical content (safety regulations, traffic regulations, etc.), since it is these violations that are in causal relationship with the resulting consequences of procedural nature unless they provide for actual legal evaluation of a person's behaviour. It is also necessary to pay attention to cases where the retroactive effect of certain provisions of a statutory legal act is directly defined therein $[12,13]$.

It should be noted that in case of adjustment of the scope of deeds recognised as a crime in virtue of changes in statutory legal acts relating to the CC RF, a person who committed a socially dangerous deed should face the same legal consequences as are usually related to factual changes in the CC RF: 5) the termination of criminal prosecution does not deprive a person of the right to appeal against the actions and decisions of the law enforcement bodies [14]; 6) the court is obliged to clarify the position of the indictee regarding the termination of the case in connection with adoption of a law lifting the criminality and punishability of the deed incriminated to him/her, and has the right to terminate the criminal case only with his/her consent. Otherwise, the court is required to consider it on the merits and pass an acquittal, or terminate the criminal case on the specified grounds [15]. The extraordinary importance of these provisions is conditioned by the fact that a person's exemption from criminal liability in connection with decriminalisation does not imply the egregiousness of his/hers guilt in the deed, but, at the same time, does not give rise to the right to rehabilitation.

The analysis of the resolutions of the RF Constitutional Court on verification under Article $212^{1}$ of the CC RF (hereinafter - the resolution with regard to Dadin's case) makes it possible to identify the key feature of the corpus delicti involving administrative prejudgement, where the legal nature of offence gives rise to many discussions in the scientific literature $[16,17]$.

7) Repeated (multiple) homogeneous (similar) administrative offences committed by a person testifies objectively to insufficiency of available administrative and legal means for efficient counteraction to such deeds, which, on a par with other factors, may be considered as a constitutionally significant reason for their criminalisation. The disposition with administrative prejudgement does not contradict to the non bis in idem principle. The classification of a crime is based on the acts prescribing administrative liability of a person, which shall enter into force and have the res judicata properties at the time of commission of a deed that caused possibly ensuing criminal liability [18].

In the conditions of amendments regularly made to the CC RF, of special relevance is the issue of a possibility to extrapolate the conclusions set out in the acts of the RF Constitutional Court to similar situations within the framework of enforcement of the same Article of the CC RF. It is important to note that this is possible when the combination of factual circumstances and regulatory legal prescriptions analysed in the course of 
decision-making by the court matches the nature of a particular case. In practice, however, quite often the attempts to appeal against the sentence are squared with the very existence of a relevant act of the RF Constitutional Court, though without regard for a limited scope of its validity.

The first type of errors identified within the framework of the present research, in terms of understanding the algorithm for applying a legal position to a specific case, is connected with comparison of factual circumstances of the case. For instance, B., convicted under Article $212^{1}$ of the CC RF, pointed out in the petition of appeal that the court of first instance had not clarified all the circumstances of the offence committed by him under Article 20.2 of the RF Administrative Offence Code, considering that the formal presence of three res judicata resolutions on bringing him to administrative liability was a sufficient measure. Moreover that the two of them were passed for his participation in the same campaign held on September 9, 2018, which was a single-time public event (as believed by B.). After analysing the circumstances of the case, Arkhangelsk Regional Court found no reason to believe that $\mathrm{B}$. had been sued under two separate occasions for the same deed, since the protest march and the rally were held within different, albeit short, time intervals, at a certain distance from each other. The interpretation of the resolution with regard to the case involving Dadin by the court of first instance was recognised as correct in relation to the deeds of B. [19].

The second type of errors in interpretation of conclusions of the RF Constitutional Court is connected with the fact that law enforcement officials do not take into account the exhaustive nature of the scope of interrelated regulatory prescriptions analysed in a specific ruling or resolution. For instance, the Supreme Court of the Udmurt Republic specified, for the defence counsel, that the conditions under which a weapon is regarded as having a cultural value for the purpose of the Federal Law "On Weapons" were absent relative to a rifle seized from the convict, and that the enforced provisions of the law are not recognised to be inconsistent with the Constitution of the Russian Federation by the resolution of the RF Constitutional Court as of June 17, 2014 No. 18-P referred to by the defence counsel [20].

The above examples clearly demonstrate the major significance of the RF Constitutional Court's acts for proper practical enforcement of the criminal law. At the same time, it is inadmissible to indiscriminately handle the legal provisions set forth in them without regard for all circumstances of a criminal case. This is a basic premise for due combination of the universal validity of the resolutions and rulings of the court, that develop the content of individual regulatory prescriptions and form proper legal consciousness in a broadest sense, and the discreteness thereof expressed in limitation of the period of their validity.

It should be also noted that the functionality of the resolutions of the RF Constitutional Court is not limited to "negative lawmaking". The withdrawal of particular criminal law provisions from the source base constitutes "positive lawmaking" at the same time, with the effect that it encourages the other systemic elements of the CC RF to "work" with additional burden (for instance, more frequent use of life imprisonment instead of death penalty). Stated differently, the acts of the RF Constitutional Court at present acquire the status of a formal source of criminal law, which creates additional guarantees for increasing the efficiency of the law enforcement activities in general.

\section{Conclusion}

Summarising the above, it is necessary to note that the development of the well-functioning theoretical concept for the institutional structure of the criminal law of the Russian Federation would be scarcely credible without regard for the specifics of the interdisciplinary relations. A promising direction for further research in this area, as viewed 
by the authors, is the search for an optimal model of interaction of the general criminal law with the domain of substantive law and procedural law, along with the implementation of the obtained results in the legislative, law enforcement and educational practice.

\section{References}

1. V.P. Konyakhin, Theoretical foundations for the construction of General Provisions of the Russian criminal law [Teoreticheskie osnovy postroeniya Obshchei chasti rossiiskogo ugolovnogo prava] (Yurid Center Press, Saint Petersburg, 2002)

2. A.I. Rarog, Lex Rus., 11(120), 46-49 (2016). https://doi.org/10.17803/1729-5920.2016.120.11.046-060

3. E.A. Smogol, Devel. Tends in Sci. and Edu. 29-1, 15-20 (2017). https://doi.org/10.18411/1j-31-08-2017-04

4. J.Á.F. Cruz, Estudios Constitucionales, 12(2), 187-238 (2014). http://dx.doi.org/10.4067/S0718-52002014000200007

5. D. Kosar, L. Vyhnanek, The Constitutional Court of Czechia. The Max Planck Handbooks in European Public Law, in Constitutional Adjudication: Institutions III, 119-179 (2020)

6. E.P. Parera, A.P. Pujolràs, Revista de Llengua i Dret, 70, 221-233 (2018). http://dx.doi.org/10.2436/rld.i70.2018.3240

7. Postanovlenie Konstitutsionnogo Suda RF ot 27 fevralya 2020 g. № 10-P "Po delu o proverke konstitutsionnosti stati 324 Ugolovnogo kodeksa Rossiiskoi Federatsii v svyazi s zhaloboi grazhdanki N.M. Demenshinoi" [Resolution of the RF Constitutional Court dated February 27, 2020 No. 10-P "With regard to the case on verification of the constitutional nature of article 324 of the Criminal Code of the Russian Federation in connection with the complaint of N.M. Demenshina"] Accessed on: June 24, 2021. [Online]. Available: https://www.garant.ru/products/ipo/prime/doc/73579193/

8. D.V. Lorentz, Rus. J. Crim. 11, 337-349 (2017). https://doi.org/10.17150/2500-4255.2017.11 (2)

9. Postanovlenie Konstitutsionnogo Suda RF ot 16.07.2015 № 22-P “Po delu o proverke konstitutsionnosti polozheniya stati 226.1 Ugolovnogo kodeksa Rossiiskoi Federatsii v svyazi s zhalobami grazhdan Respubliki Kazakhstan O.E. Nedashkovskogo i S.P. Yakovleva" [Resolution of the RF Constitutional Court dated July 16, 2015 No. 22-P "With regard to the case on verification of the constitutional nature of provision of article 226.1 of the Criminal Code of the Russian Federation in connection with the complaints of the citizens of the Republic of Kazakhstan, O.E. Nedashkovsky and S.P. Yakovlev"] Accessed on: June 24, 2021. [Online]. Available: http://www.consultant.ru/document/cons_doc_LAW_183260/

10. Opredelenie Konstitutsionnogo Suda RF ot 10.07.2003 № 270-O “Ob otkaze v prinyatii k rassmotreniyu zaprosa Kurganskogo gorodskogo suda Kurganskoi oblasti o proverke konstitutsionnosti chasti pervoi stati 3, stati 10 Ugolovnogo kodeksa Rossiiskoi Federatsii i punkta 13 stati 397 Ugolovno-protsessualnogo kodeksa Rossiiskoi Federatsii" [Ruling of the RF Constitutional Court of 10.07.2003 No. 270-O "On refusal to accept the request of Kurgan City Court of Kurgan Region on verification of the constitutional nature of part one of Article 3, of Article 10 of the Criminal Code of the Russian Federation and clause 13 of Article 397 of the Russian Federation Code of Criminal Procedure"'] Accessed on: June 24, 2021. [Online]. 
Available:

https://legalacts.ru/doc/opredelenie-konstitutsionnogo-suda-rf-ot-10072003-n-270-o-ob /

11. Postanovlenie Konstitutsionnogo Suda RF ot 14.06.2018 № 23-P Po delu o proverke konstitutsionnosti chasti 1 stati 1.7 i chasti 4 stati 4.5 Kodeksa Rossiiskoi Federatsii ob administrativnykh pravonarusheniyakh, punkta 4 stati 1 Federalnogo zakona "O vnesenii izmenenii v Ugolovnyi kodeks Rossiiskoi Federatsii i Ugolovno-protsessualnyi kodeks Rossiiskoi Federatsii po voprosam sovershenstvovaniya osnovanii i poryadka osvobozhdeniya ot ugolovnoi otvetstvennosti" i punkta 4 stati 1 Federalnogo zakona "O vnesenii izmenenii v otdelnye zakonodatelnye akty Rossiiskoi Federatsii v svyazi s prinyatiem Federalnogo zakona "O vnesenii izmenenii v Ugolovnyi kodeks Rossiiskoi Federatsii i Ugolovno-protsessualnyi kodeks Rossiiskoi Federatsii po voprosam sovershenstvovaniya osnovanii i poryadka osvobozhdeniya ot ugolovnoi otvetstvennosti" v svyazi s zhalobami grazhdan A.I. Zalyautdinova, N.Ya. Ismagilova i O.V. Cherednyak" [Resolution of the RF Constitutional Court dated June 14, 2018 No. 23-P "With regard to the case on verification of the constitutional nature of part 1 of Article 1.7 and part 4 of Article 4.5 of the RF Administrative Offence Code, clause 4 of Article 1 of the Federal Law "On amendments to the Russian Federation Criminal Code and the Russian Federation Code of Criminal Procedure on revising the grounds and the procedure for exemption from criminal liability" and clause 4 of Article 1 of the Federal Law "On amendments to a number of legislative acts of the Russian Federation in connection with the adoption of the Federal Law "On amendments to the Russian Federation Criminal Code and the Russian Federation Code of Criminal Procedure on revising the grounds and the procedure for exemption from criminal liability" in connection with the complaints of A.I. Zalyautdinov, N.Ya. Ismagilov and O.V. Cherednyak"] Accessed on: June 24, 2021. [Online]. Available: https://legalacts.ru/sud/postanovlenie-konstitutsionnogo-suda-rf-ot-14062018-n-23-p/

12. A.I. Chuchaev (ed.), Kommentarii k Ugolovnomu kodeksu Rossiiskoi Federatsii (nauchno-prakticheskii) [Commentary to the Criminal Code of the Russian Federation (scientific and practical)] (Prospect, Moscow, 2019)

13. K.V. Obrazhiev, Crim. Law 2, 59-66 (2016)

14. Postanovlenie Konstitutsionnogo suda Possiiskoi Federatsii po delu o proverke konstitutsionnosti polozhenii chasti pervoi stati 10 Ugolovnogo kodeksa Rossiiskoi Federatsii, chasti vtoroi stati 24 , chasti vtoroi stati 27 , chasti chetvertoi stati 133 i stati 212 Ugolovno-protsessualnogo kodeksa Rossiiskoi Federatsii v svyazi s zhalobami grazhdan S.A.Borovkova i N.I.Morozova [Resolution of the Constitutional Court of the Russian Federation with regard to the case on verification of the constitutional nature of provisions of part one of Article 10 of the Criminal Code of the Russian Federation, part two of Article 24, part two of Article 27, part four of Article 133 and Article 212 of the Russian Federation Code of Criminal Procedure in connection with the complaints of S.A. Borovkov and N.I. Morozov] Accessed on: June 24, 2021. [Online]. Available: http://pravo.gov.ru/proxy/ips/?docbody=\&nd=102169126

15. Postanovlenie Konstitutsionnogo Suda RF ot 15.10.2018 № 36-P “Po delu o proverke konstitutsionnosti chasti pervoi stati 10 Ugolovnogo kodeksa Rossiiskoi Federatsii, chasti vtoroi stati 24, chasti vtoroi stati 27, chasti pervoi stati 239 i punkta 1 stati 254 Ugolovno-protsessualnogo kodeksa Rossiiskoi Federatsii v svyazi s zhaloboi grazhdanki A.I. Tikhomolovoi" [Resolution of the RF Constitutional Court of 15.10.2018 No. 36-P "With regard to the case on verification of the constitutional 
nature of part one of Article 10 of the Criminal Code of the Russian Federation, part two of Article 24, part two of Article 27, part one of Article 239 and clause 1 of Article 254 of the Russian Federation Code of Criminal Procedure in connection with the complaint of A.I. Tikhomolova"] Accessed on: June 24, 2021. [Online]. Available: http://www.consultant.ru/document/cons_doc_LAW_309039/

16. A.V. Ivanchin, Bul. Yaroslavl Demidov State Univ. Ser.: Humanit. 2(40), 65-71 (2017)

17. A.D. Nechaev, Compar. Constit. Rev. 3(118), 134-147 (2017)

18. Postanovlenie Konstitutsionnogo Suda RF ot 10 fevralya 2017 g. № 2-P “Po delu o proverke konstitutsionnosti polozhenii stati 212.1 Ugolovnogo kodeksa Rossiiskoi Federatsii v svyazi s zhaloboi grazhdanina I.I. Dadina" [Resolution of the Constitutional Court of the Russian Federation No. 2-P of February 10, 2017 "In the case of checking the constitutionality of the provisions of Article 212.1 of the Criminal Code of the Russian Federation in connection with the complaint of citizen I. I.

Dadin"] Accessed on: June 24, 2021. [Online]. Available: http://www.garant.ru/products/ipo/prime/doc/71509066/\#ixzz6yhjrac8s

19. Apellyatsionnoe postanovlenie № 22-3271/2019 ot 29 noyabrya 2019 g. po delu № 1-292/2019 [Appellate resolution No. 22-3271/2019 dated November 29, 2019 with regard to case No. 1-292/2019] Accessed on: June 24, 2021. [Online]. Available: https://sudact.ru/regular/doc/cj47V72ocwQ9/

20. Apellyatsionnoe postanovlenie № 22-2119/2019 ot 17 dekabrya 2019 g. po delu № 1-76/2019 [Appellate resolution No. 22-2119/2019 of December 17, 2019 with regard to case No. 1-76/2019] Accessed on: June 24, 2021. [Online]. Available: https://sudact.ru/regular/doc/1NFt0Xg2li54/ 